\title{
Praktische huisartsgeneeskunde
}

\section{Urogynaecologie}
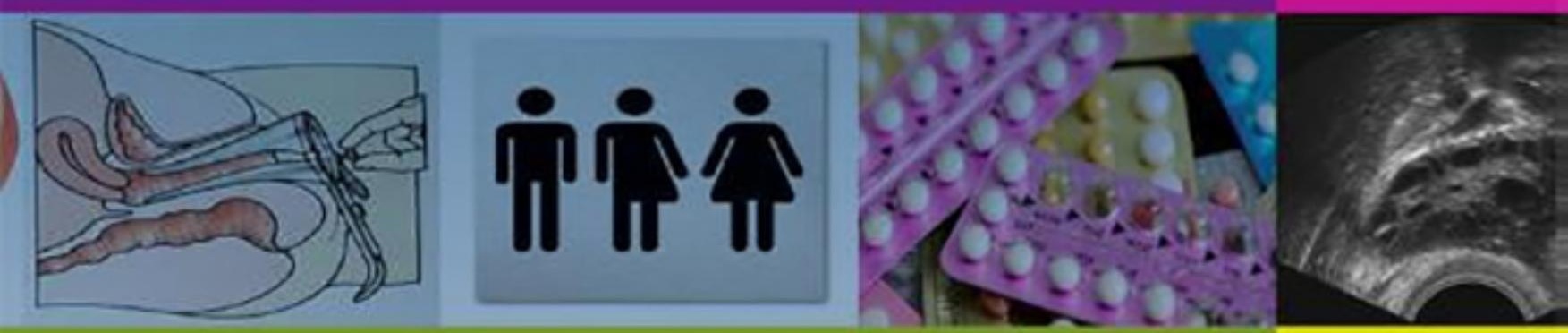

Onder redactie van:

Toine Lagro-Janssen

Doreth Teunissen 


\section{Epidemiologie van urogynaecologie}

G.A. Donker

\section{Samenvatting}

Wist $u$ dat menstruatiepijn typisch een klacht is voor jonge vrouwen van 15-24 jaar? En dat een derde van de vrouwen niet normaal kan functioneren tijdens de menstruatie? Dit hoofdstuk laat ook trends in de laatste vijf jaar zien: de prevalentie van urine-incontinentie gepresenteerd aan de huisarts neemt af bij vrouwen, seksueel overdraagbare aandoeningen laten grote manvrouwverschillen zien en syfilis komt bij vrouwen weinig voor en wordt vooral overgedragen door MSM-contacten, terwijl herpes genitalis juist meer voorkomt bij vrouwen dan bij mannen. En wist $u$ dat blaas- en niercarcinoom bij mannen veel meer voorkomen dan bij vrouwen en dat blaascarcinoom bij mannen een toenemende trend laat zien? Het gebruik van anticonceptie is de laatste vijf jaar weinig veranderd: nieuwe methoden maken geen opmars en de tweedegeneratiepil blijft het populairste middel. Het lijkt vooral een vrouwenzaak, maar mannen laten zich wel vier keer zo vaak steriliseren als vrouwen.

$1.1 \quad$ Inleiding - 5

1.2 Menstruatieproblemen -5

1.3 Fluorklachten -8

1.4 Seksueel overdraagbare aandoeningen - 9

1.5 Overgangs- en LUTS-klachten - 11

$1.6 \quad$ Urineweginfecties -11

1.7 De bekkenbodem - 13

$1.8 \quad$ Fertiliteit - 16

(c) Bohn Stafleu van Loghum is een imprint van Springer Media B.V., onderdeel van Springer Nature 2020 T. Lagro-Janssen en D. Teunissen (Red.), Urogynaecologie, Praktische huisartsgeneeskunde, https://doi.org/10.1007/978-90-368-2409-5_1 
1.9 Mannelijke uitwendige genitalia - 18

1.10 Maligne aandoeningen - 19

1.11 Tot slot -23

Literatuur - 23 